\title{
Comparison of Season-Long Grazing Applied Annually and a 2-Year Rotation of Intensive Early Stocking Plus Late-Season Grazing and Season-Long Grazing
}

\author{
Clenton E. Owensby ${ }^{1}$ and Lisa M. Auen ${ }^{2}$ \\ Authors are: ${ }^{1}$ Professor of Range Management and ${ }^{2}$ Assistant Scientist in Range Management, Department of Agronomy, Kansas State University, \\ Manhattan, KS 66506, USA.
}

\begin{abstract}
This research measured steer gains, aboveground biomass remaining at the end of the growing season, and economic returns of tallgrass prairie grazed under season-long stocking (SLS-C) and a grazing system that included a 2-yr rotation of SLS-rotated (SLS-R) and intensive early stocking (IES; $2 \times$ normal stocking rate) + late-season grazing at the normal stocking rate (IES + LSG$\mathrm{R})$. We hypothesized that even though the stocking rate on the IES +LSG-R pasture was above the recommended rate, the greater regrowth availability in the late season would result in steers gaining as well as or better than those stocked SLS at the normal rate. By rotating the IES+LSG treatment with SLS over 2 yr, we anticipated that the aboveground biomass productive capacity of the IES + LSG pasture would be restored in one growing season. Further, we hypothesized that the increased stocking rate with IES + LSG would increase net profit. Comparing traditional season-long stocking to the system, which was a combination of SLS and IES+LSG rotated sequentially over a 2 -yr period, the system increased steer gains by $7 \mathrm{~kg} \cdot \mathrm{hd}{ }^{-1}$ and by $30 \mathrm{~kg} \cdot \mathrm{ha}^{-1}$, had a consistent reduction of $429 \mathrm{~kg} \cdot \mathrm{ha}^{-1}$ biomass productivity, and increased net profit by $\$ 55.19$ per steer and $\$ 34.28$ per hectare.
\end{abstract}

Key Words: biomass production, grazing systems, intensive early stocking, net returns, season-long stocking, steer gains, tallgrass prairie

\section{INTRODUCTION}

Stocking rate has been shown by a plethora of stocking rate studies to be the greatest influence on individual animal performance (Holechek et al. 1999) with a linear decline in individual animal performance with increasing stocking rate. Yet the response to stocking rate has not been highly correlated with herbage availability. Rangelands are notoriously variable in herbage production from year to year, induced largely by variability of precipitation. However, the individual animal response to stocking rate remains relatively constant in central and eastern Kansas grassland communities regardless of fluctuations in herbage production (Launchbaugh and Owensby 1978). Also, at all stocking rates, individual livestock gains decline as the growing season progresses in response to declines in forage quality. Pieschel (1980) used samples obtained by esophageally fistulated steers to measure forage quality on Kansas Flint Hills range, showing substantial declines in those traits that enhance forage quality. The mechanism for the causes for individual animal gains to be reduced more by high stocking rates is complex. Simply stating that animals are forced to consume lower-quality forage does not reveal the reason for that reduction in gain. First, the reduction in gain in central and eastern Kansas rangelands is not uniformly distributed throughout the growing season. During the first half of the growing season on areas stocked by steers

Contribution No. 13-007-J from the Kansas Agricultural Experiment Station.

Correspondence: Clenton E. Owensby, Kansas State University, Dept of Agronomy,

Throckmorton Hall, Manhattan, KS 66506-5501, USA. Email: owensby@ksu.edu

Manuscript received 16 January 2013; manuscript accepted 13 August 2013

(c) 2013 The Society for Range Management continuously throughout the growing season at heavy, moderate, and light rates, steers gain similarly regardless of stocking rate, but during the latter half of the season, steers on heavily stocked pastures gain less than those on moderately or lightly stocked range (Launchbaugh and Owensby 1978). Smith and Owensby (1978) designed the intensive early stocking system (IES) commonly used in the Kansas Flint Hills using that circumstance that is incorporated into this study. Typically, the Kansas Flint Hills are either stocked growing season-long until October 1 by $\sim 250 \mathrm{~kg}$ steers at $1.62 \mathrm{ha} \cdot$ steer $^{-1}$ or intensive early stocked at $0.81 \mathrm{ha} \cdot$ steer $^{-1}$ until mid-July.

The difference in late-growing-season individual steer gain centers on consumption of poorer-quality forage. Cattle create grazed patches during the early season and revisit them frequently as the season progresses (Streeter et al. 1974; McNaughton 1986; Ring et al. 1985; Coughenour 1991; Brock 1997). They do so because forage quality is greater there due to regrowth of previously grazed plants (Hobbs and Swift 1988; Chapin and McNaughton 1989; Briske et al. 2008). As a plant matures, it increases in less digestible fiber components, and nutrient concentrations decline in part due to mobilization of chemical constituents and storage of those constituents in stem bases and rhizomes, which are necessary for regrowth following defoliation or frost (Owensby et al. 1977). On those patches created by steers in the early season, regrowth produces new young leaves by use of the stored constituents required for growth (Milchunas et al. 2005). Therefore, the proportion of the animal's diet derived from regrowth in the latter half of the growing season will influence their late-season gain. Brock (1997) reported that in Kansas Flint Hills range grazed by yearling steers, increasing the stocking rate to twice the normal rate increased the area grazed by only 1.45 times that under the 
normal rate. Unpublished data taken in that study showed a substantial increase in the number of times that a tiller on the heavily grazed area was grazed. Briske and Stuth (1982) reported a similar response. The impact of the failure of the area grazed to be proportionate to the increased stocking rate was a reduced total area per steer with regrowth available for grazing. Tillers on the reduced grazed area per steer would be grazed a greater number of times and likely would have a reduction in their productive capacity. We suggest that the reason for the substantial reduction in steer gains in late season under heavy stocking in central and eastern Kansas rangelands is due to a reduction in the proportion of the diet coming from regrowth.

Most studies that used preconditioning of areas using grazing to increase forage quality for subsequent use have been centered on improving fall and winter diets for wildlife populations (Pitt 1986; Clark et al. 1998; Arsenault and Owen-Smith 2002; Verweij et al. 2006). In the Nebraska Sandhills, Lamb et al. (1997) showed that cows using regrowth on previously hayed subirrigated meadows had increased weaning weights for their calves. Recent research in the Kansas Flint Hills has shown that preconditioning forage on an area by grazing at a high stocking density in the early season followed by a lower stocking density in the late season resulted in an increased season-long individual steer gain even though the stocking rate for the season was greater than the traditional rate (Owensby et al. 2008). They reported that increased regrowth availability in the late season likely allowed for an increased stocking rate without a reduction in individual animal gain for animals that grazed the entire grazing season. Harmoney and Jaeger (2011) reported that a similar grazing scheme in a central Kansas shortgrass prairie, which they termed "modified intensive-early stocking," also showed no reduction in per head gains. Indeed, in the Flint Hills study, those animals that grazed the entire season where the pasture had been preconditioned by grazing at twice the normal rate had a higher season-long gain than steers that grazed at the normal season-long stocking rate. That study included a 3-yr rotation of season-long stocking (SLS), IES, and IES with late-season grazing (IES+LSG) so that the reduction in plant vigor under the high stocking rate of the IES + LSG treatment could be mitigated by 2 yr of stocking at the normal season-long rate with SLS and IES. Data from that study showed that it was likely that bluestem range could recover productive capacity by grazing at the normal SLS rate for only one season following the IES + LSG treatment.

We hypothesize the following:

1. Increased early-season grazing at twice the moderate rate followed by grazing at the normal rate during the latter half of the grazing season will increase steer gains per head on those steers that are grazed growing season-long compared to steers grazed season-long each year at the normal rate.

2. Herbage remaining under season-long stocking at a moderate rate the year following the intensive early-season grazing plus late-season grazing will be equal to that of pastures stocked season-long year each year at the same rate.
3. Increased stocking rate will result in a substantially greater net profit for the 2-yr rotation of IES + LSG and SLS than for yearly SLS.

The objective of the study reported here was to measure and compare steer weight gains per head and daily gains, biomass production, and net returns on Kansas Flint Hills bluestem range grazed SLS yearly and in a 2 -yr rotation of SLS and IES+LSG.

\section{MATERIALS AND METHODS}

\section{Experimental Area}

Research was conducted from 2001 through 2010 on the Rannells Flint Hills Prairie Preserve near Manhattan, Kansas (lat $39^{\circ} 12^{\prime} \mathrm{N}$, long $96^{\circ} 35^{\prime} \mathrm{W}, 324 \mathrm{~m}$ above mean sea level). Vegetation on the site was a mixture of $\mathrm{C}_{3}$ and $\mathrm{C}_{4}$ species, dominated by the $\mathrm{C}_{4}$ warm-season grasses Andropogon gerardii Vitman, Sorghastrum nutans (L.) Nash., and Andropogon scoparius Michx. Total warm-season perennial grasses made up $85 \%$ of the plant composition. Poa pratensis L., and members of the Cyperaceae $\left(\mathrm{C}_{3}\right)$ made up $5-7 \%$. Principal forbs (all $\mathrm{C}_{3}$ warm-season) also made up $5-7 \%$ of the stand and included Vernonia baldwinii var. interior (Small) Schub., Ambrosia psilostachya DC., Artemisia ludoviciana Nutt., and Psoralea tenuiflora var. floribunda (Nutt.) Rydb. Average peak aboveground biomass (dry wt) of $425 \mathrm{~g} \cdot \mathrm{m}^{-2}$ usually occurs in early August, of which $35 \mathrm{~g} \cdot \mathrm{m}^{-2}$ is from forbs (Anderson et al. 1970). The 30-yr average annual precipitation is $840 \mathrm{~mm}$, with $520 \mathrm{~mm}$ occurring during the growing season.

The six grazing units used in the study ranged in size from 61 to 97 ha and were annually burned in late April. Each grazing unit contained comparable amounts of loamy upland, breaks, clay upland, shallow limey, and lowland range sites. Prior to the beginning of the study, all grazing units were burned annually in the latter part of April and grazed seasonlong by steers for several decades. Steers are usually placed on the pastures 7-10 d following burning when sufficient growth has occurred to sustain them. Late-spring burning is the preferred time for maximum steer gains and maintenance a healthy grassland ecosystem in the Kansas Flint Hills (Anderson et al. 1970). Burning increases the steer gains by $14 \mathrm{~kg}$ in the season when burning occurs at the beginning of leaf emergence of the dominant warm-season grasses (Launchbaugh and Owensby 1978).

\section{Grazing Treatments}

Three grazing units were grazed season-long each year at 1.62 ha $\cdot$ steer $^{-1}$ (SLS-C), and three grazing units were grazed at $0.81 \mathrm{ha} \cdot$ steer $^{-1}$ until mid-July (IES+LSG-IES) followed by late-season stocking at $1.62 \mathrm{ha} \cdot$ steer $^{-1}$ until 1 October in year 1 (IES+LSG-SL) and grazed season-long (SLS-R) at 1.62 ha. steer ${ }^{-1}$ the following year (Fig. 1). All three replicate pastures in the 2-yr rotation were stocked the same in a given year, either SLS-R or IES+LSG. Treatments were randomly allocated among grazing units at the beginning of the study. The duration of the study was $10 \mathrm{yr}$. Twelve yearling steers per grazing unit were individually tagged and weighed in late April or early May and in late September or early October. 
System

Continuous

Season Long Grazing

(SLS-C)
Intensive Early Stocking

+ Late Season Grazing and

Season Long Grazing

(IES+LSG and SLS-R

2 year rotation)

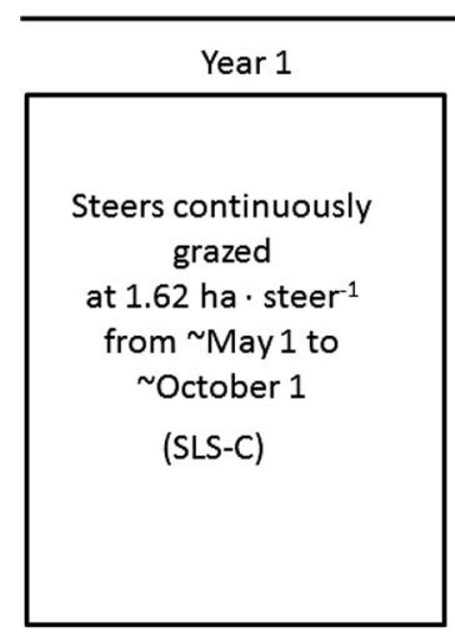

Year 2

Steers continuously

grazed

at 1.62 ha steer $^{-1}$

from May 1 to

October 1

(SLS-C)
Year 1

Steers grazed at

0.81 ha $\cdot$ steer $^{-1}$

from May 1 to

July 15

(IES+LSG-IES)

Steers grazed at

1.62 ha steer $^{-1}$

from July 15 to

October 1

(IES+LSG-SL)

Year 2

Steers continuously

grazed

at $1.62 \mathrm{ha} \cdot$ steer $^{-1}$

from May 1 to

October 1

(SLS-R)
Figure 1. Yearly treatments for continuous season-long stocking and the system with intensive early stocking at $2 \times$ the season-long rate followed by late-season grazing on the same grazing unit at the season-long rate $(1 \times)$ in year 1 and season-long grazing in year 2. Normal Kansas Flint Hills grazing is either season-long stocking from around 1 May to around 1 October at $1.62 \mathrm{ha} \cdot$ steer $^{-1}$ or intensive early stocking from around 1 May to 15 July at 0.81 ha $\cdot$ steer $^{-1}$. Steers are placed in the feedlot following season-long grazing or intensive early stocking.

Tagged steers within the IES+LSG-IES treatment were also weighed in mid-July and were retained on the pasture and weighed again in late September or early October. Steers averaged $\sim 250 \mathrm{~kg}$ at initial stocking, $\sim 336 \mathrm{~kg}$ in mid-July, and $\sim 370 \mathrm{~kg}$ on 1 October during the course of the study. Grazing unit size varied from 61 to 97 ha.

\section{Aboveground Biomass Sampling}

Aboveground biomass was determined in early October from 2001 through 2010 by clipping quadrats to ground level. Six each $0.5 \times 0.5 \mathrm{~m}$ quadrats were equally spaced along permanently located $100-\mathrm{m}$ transects in loamy upland range sites equidistant from water in each grazing unit. Grasses and forbs were separated and dried to a constant weight at $55^{\circ} \mathrm{C}$.
Economic Analysis

The economic analysis was performed by developing costreturn budgets (per head and per hectare) for each of the grazing schemes (SLS-C, SLS-R, and IES+LSG-SL, and the system). Cost estimates were based on projected and actual grazing budgets for native range grazing with steers in eastern Kansas (Dhuyvetter 2012) as well as actual costs that occurred in the research trials where appropriate. Costs for pasture were examined as a cost per head for the grazing period. Pasture rental rates were fixed at $\$ 39.50$ per hectare. Cattle prices for 202-224-kg steer calves in May (purchase price) and 284-324$\mathrm{kg}$ feeder steers in July and October (sale price) were used for each year of the study from Monthly Feeder Cattle and Western Kansas Slaughter Cattle Prices-Includes Value of Gain and Seasonal Price Indices (Kansas Farm Management Association 2012). Initial weight and weight in July or October were the means for the 10-yr period since there was no significant yearby-treatment interaction $(P=0.58)$. Using those means and the market data allowed for yearly budgets for the $10 \mathrm{yr}$ of the study.

Budgets were developed on a per head basis initially, as this is typically how costs and returns are reported. Returns per head were adjusted by stocking rate to convert them to a per hectare basis to allow comparisons across the grazing programs. Returns per hectare, as opposed to returns per head, is the relevant measure if the land base is the constraining resource. That is, a producer with a fixed amount of land will want to maximize the returns and/or minimize the risk per hectare as opposed to per head.

\section{Statistical Analysis}

Steer gain and aboveground biomass data were analyzed as a split plot in time with grazing treatment the main effects using the SAS-GLM analysis of variance (2012) procedure (SAS Institute, Cary, NC). Probabilities of a significant difference are reported and means separated using Duncan's multiple range tests $(P<0.10)$. We also calculated the linear trend over the 10 yr period of the difference in biomass remaining after grazing on SLS and IES+LSG pastures.

\section{RESULTS}

\section{Steer Gains}

The treatment-by-year interaction for per head and per hectare gains was not significant $(P=0.58)$; therefore, 10 -yr means are used to discuss differences due to treatment.

Per Head Gains. Average SLS-C gains were significantly less than IES+LSG-SL gains in all years $(P<0.09$; Table 1$)$. Steers removed in July (IES+LSG-IES) gained less than those grazed season-long $(P<0.09)$ because they grazed only half as long as the SLS steers.

Per Hectare Gain. Steer gains per hectare were lowest for the SLS-C pastures, intermediate for IES+LSG-SL, and highest when the IES+LSG-IES steer gains and IES+LSG-SL gains were combined $(P=0.09$; Table 1$)$. Gains per hectare for the IES+LSG-SL were greater than those for SLS-C. 
Table 1. Steer gains $\left(\mathrm{kg} \cdot \mathrm{head}^{-1}\right.$ and $\left.\mathrm{kg} \cdot \mathrm{ha}^{-1}\right)$ for steers grazed season-long applied annually (SLS-C), steers grazed season-long following intensive early stocking (IES + LSG-SL), and steers grazed IES and removed in mid-July from the IES + LSG treatment (IES $+\mathrm{LSG}-\mathrm{IES})$. The $\mathrm{kg} \cdot \mathrm{ha}^{-1} \mathrm{values}$ for steers grazed season-long and those removed in mid-July for the IES + LSG pastures were combined to get a $\mathrm{kg} \cdot \mathrm{ha}^{-1}$ value. The system gains $\left(\mathrm{kg} \cdot \mathrm{ha}^{-1}\right.$ ) are a mean of two consecutive years, that is, 2001-2002, 2003-2004, and so on. The year $\times$ treatment interaction was not significant; therefore, mean steer gains $\left(\mathrm{kg} \cdot\right.$ head $^{-1}$ or $\left.\mathrm{kg} \cdot \mathrm{ha}^{-1}\right)$ with a common letter do not differ (Duncan's multiple range test $[P<0.10]$ ).

\begin{tabular}{|c|c|c|c|c|c|c|c|c|}
\hline & \multicolumn{3}{|c|}{$\mathrm{kg} \cdot \mathrm{head}^{-1}$} & \multicolumn{5}{|c|}{$\mathrm{kg} \cdot \mathrm{ha}^{-1}$} \\
\hline & SLS-C & IES + LSG-SL & IES + LSG-IES & SLS-C & IES + LSG-SL & IES + LSG-IES & Combined & System \\
\hline 2001 & 106 & 105 & 68 & 66 & 65 & 37 & 102 & \\
\hline 2002 & 139 & 146 & & 86 & 91 & & & 96 \\
\hline 2003 & 126 & 131 & 92 & 78 & 103 & 51 & 154 & \\
\hline 2004 & 129 & 132 & & 80 & 82 & & & 118 \\
\hline 2005 & 117 & 121 & 85 & 73 & 75 & 47 & 122 & \\
\hline 2006 & 98 & 107 & & 61 & 66 & & & 94 \\
\hline 2007 & 139 & 141 & 87 & 86 & 90 & 48 & 138 & \\
\hline 2008 & 114 & 119 & & 70 & 75 & & & 106 \\
\hline 2009 & 119 & 137 & 100 & 74 & 83 & 55 & 138 & \\
\hline 2010 & 112 & 137 & & 71 & 84 & & & 111 \\
\hline Mean & $121 \mathrm{a}$ & $128 \mathrm{~b}$ & $86 c$ & $75 a$ & $79 \mathrm{~b}$ & $48 \mathrm{c}$ & 131 & 105 \\
\hline
\end{tabular}

\section{Aboveground Biomass}

The treatment-by-year interaction for grass and forb aboveground biomass was not significant $(P=0.78$ and 0.64 , respectively). Therefore, aboveground biomass means over the 10 -yr period are reported.

October Grass Aboveground Biomass. At the end of the grazing season, grass aboveground biomass on SLS-C was greater than on the pastures grazed IES+LSG or SLS-R $(P=0.10$; Table 2).

October Forb Aboveground Biomass. Forb aboveground biomass did not differ for the SLS-C, IES+LSG, or SLS-R treatments $(P=0.80$; Table 2$)$.

\section{Economic Analysis}

When pasture rent is charged on a per head basis, net returns per hectare are highest with the system, which includes an SLS$\mathrm{R}$ and a combined IES+LSG-IES and IES+LSG-SL grazing unit, and lowest for SLS-C (Table 3). Across the $10 \mathrm{yr}$, returns were highest for the system every year. SLS-C steers always had lower net returns compared to SLS-R and IES+LSG-SL grazed steers. In 6 of the 10 years, IES+LSG-SL and SLS-R steers had higher net returns than IES+LSG-IES grazed steers. Combining the net returns per steer and per hectare for the IES+LSG-SL and the IES+LSG-IES steers for a grazing unit gave the highest net returns each year.

Table 2. Grass and forb aboveground biomass $\left(\mathrm{kg} \cdot \mathrm{ha}^{-1}\right)$ in early October for season-long stocking applied annually (SLS-C) and IES + LSG and SLS$\mathrm{R}$ in a 2-yr rotation. Means (10-yr average) within a row with a common letter do not differ $(P<0.10)$.

\begin{tabular}{lccccc}
\hline & \multicolumn{2}{c}{ SLS } & & \multicolumn{2}{c}{ IES+LSG } \\
\cline { 2 - 3 } \cline { 5 - 6 } & $\left(\mathrm{kg} \cdot \mathrm{ha}^{-1}\right)$ & SE $(0.10)$ & & $\left(\mathrm{kg} \cdot \mathrm{ha}^{-1}\right)$ & SE $(0.10)$ \\
\hline Grass & $1902 \mathrm{a}$ & $( \pm 226)$ & & $1572 \mathrm{~b}$ & $( \pm 227)$ \\
Forbs & $282 \mathrm{a}$ & $( \pm 35)$ & $277 \mathrm{a}$ & $( \pm 40)$ \\
\hline
\end{tabular}

\section{DISCUSSION}

The goal of this research was to increase stocking rates without sacrificing individual animal gains and thereby increase net profit. Typically, increasing stocking rates above a peril point causes individual steer gains to decline. Previous research by Brock (1997) indicated the likely reason for that decline; that is, regrowth in the diet made up a lower percentage of the diet under heavy stocking. Previous research in the northern Kansas Flint Hills has shown that there is an adequate quantity of forage under heavy stocking rates ( $80 \%$ removal rate) such that quantity was not the factor limiting steer gains but that forage quality limited their gain (Launchbaugh and Owensby 1978). In order to improve forage quality in the late growing season, grazing at twice the season-long rate during the early part of the season increased the area grazed and subsequently the amount of regrowth available for steers grazing in the late season. We have called that preconditioning late-season forage quality. Similar to the previous study using IES+LSG (Owensby et al. 2008), steers with a preconditioning of the late-season forage by grazing at twice the season-long stocking rate in the first half of the season followed by grazing at the season-long rate during the latter half increased the per head steer gains for steer grazed season-long compared to those steers that were grazed at the normal season-long stocking rate each year. Although there was no diet selection data collected, the fact that under an increased stocking rate there was an increase in gain for steers that grazed season-long following intensive early stocking implies that a higher quality forage was available to those steers compared to those stocked growing season-long at the normal rate. Unexpectedly, the steers that were grazed season-long at the normal stocking rate the following year (SLS-R) also gained more than those steers that were grazed at the normal season-long stocking rate each year.

Since the budgets comparing the different treatments were for a 10-yr period, they included both adverse weather and marketing conditions. The budgets represent a potential implementation of the system where an operator has multiple 
Table 3. Net returns per head and per hectare for different grazing schemes. The values were derived using market prices for each year and mean steers gains for the 10-yr study period. SLS-C net returns are for steers grazed season-long each year. SLS-R net returns are for steers grazed SLS the year following IES+LSG. IES+LSG-IES net returns for those steers removed in mid-July. The IES+LSG net returns are a combination of the IES+LSG-SL and IES+LSG-IES for one grazing unit. The system returns per head are a 5-yr mean of the SLS-R units combined with a 10-yr mean of the IES + LSG unit for a given year. Returns in parentheses are negative.

\begin{tabular}{|c|c|c|c|c|c|}
\hline Year & SLS-C (per steer) & SLS-R (per steer) & IES + LSG-IES (per steer) & IES + LSG (per steer) & System (per steer) \\
\hline 2001 & $\$ 34.12$ & $\$ 46.65$ & $\$ 46.35$ & $\$ 93.00$ & $\$ 69.83$ \\
\hline 2002 & $\$ 22.63$ & $\$ 34.12$ & $(\$ 4.33)$ & $\$ 29.79$ & $\$ 31.96$ \\
\hline 2003 & $\$ 217.02$ & $\$ 233.72$ & $\$ 85.37$ & $\$ 319.09$ & $\$ 276.41$ \\
\hline 2004 & $\$ 185.55$ & $\$ 203.66$ & $\$ 295.62$ & $\$ 499.28$ & $\$ 351.47$ \\
\hline 2005 & $\$ 72.54$ & $\$ 89.28$ & $(\$ 12.14)$ & $\$ 77.14$ & $\$ 83.21$ \\
\hline 2006 & $\$ 76.84$ & $\$ 92.75$ & $\$ 105.42$ & $\$ 198.17$ & $\$ 145.46$ \\
\hline 2007 & $\$ 89.88$ & $\$ 106.42$ & $\$ 82.33$ & $\$ 188.75$ & $\$ 147.59$ \\
\hline 2008 & $\$ 6.66$ & $\$ 20.06$ & $\$ 114.64$ & $\$ 134.70$ & $\$ 77.38$ \\
\hline 2009 & $(\$ 20.82)$ & $(\$ 8.60)$ & $\$ 54.85$ & $\$ 46.25$ & $\$ 18.83$ \\
\hline 2010 & $\$ 37.24$ & $\$ 52.78$ & $\$ 37.34$ & $\$ 90.12$ & $\$ 71.45$ \\
\hline Per steer mean & $\$ 72.17$ & $\$ 87.08$ & $\$ 80.55$ & $\$ 167.63$ & $\$ 127.36$ \\
\hline Per hectare mean & $\$ 44.82$ & $\$ 54.09$ & $\$ 50.03$ & $\$ 104.12$ & $\$ 79.10$ \\
\hline Standard error, $\$ \cdot h^{-1}$ & $\$ 72.27$ & $\$ 74.00$ & $\$ 82.19$ & $\$ 137.44$ & $\$ 102.44$ \\
\hline Coefficient of variation, \% & 100 & 85 & 102 & 82 & 80 \\
\hline Minimum $\$ \cdot \mathrm{ha}^{-1}$ & $(\$ 11.5)$ & $(\$ 4.75)$ & $(\$ 2.39)$ & $\$ 16.46$ & $\$ 10.40$ \\
\hline Average of worst $5 \mathrm{yr}, \$ \cdot \mathrm{ha}^{-1}$ & $\$ 12.72$ & $\$ 16.02$ & $\$ 13.49$ & $\$ 37.16$ & $\$ 29.77$ \\
\hline
\end{tabular}

pastures and stocks one IES+LSG and another at SLS. It is assumed that the pastures would be rotated between each other. Net returns per hectare for the system (an SLS-R and an IES + LSG combination) were almost twice those for the SLS-C treatment. In addition to the greater net returns for the system, an additional benefit was reduced risk (Table 3). Owensby et al. (2008) concluded that there was reduced risk for a system that included IES+LSG, SLS-R, and IES-R in a 3-yr rotation due to the marketing of steers at two different times each year. Obviously, increasing stocking rate with increased per steer gains brings a greater net return with a fixed land resource. The question arises as to the sustainability of this practice due to the reduced grass biomass remaining at the end of the growing season on the system pastures. Accordingly, we analyzed the linear trend in biomass production and found that there was no

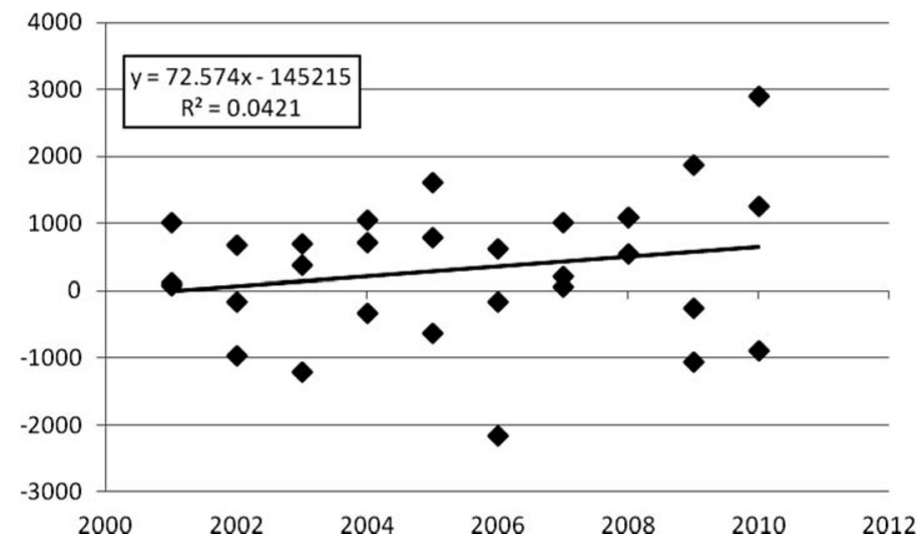

Figure 2. Regression of the difference between biomass remaining after grazing on season-long stocked (SLS) pastures and intensive early stocking + late-season stocked pastures (IES+LSG). linear decline in productivity in the system pastures compared to the SLS-C pastures $(P=0.51)$.

Based on the study reported by Owensby et al. (2008), we anticipated that the SLS-R treatment following IES+LSG would be sufficient to restore productivity of the plant community to that of the SLS-C pastures. That appears not to be the case. However, the lack of evidence of a linear decline over a 10 -yr period may indicate that this is a sustainable practice (Fig. 2).

Annual precipitation does not appear to have impacted steer gains greatly (Fig. 3). The tendency was for gains to be better during dry years, a phenomenon the authors have witnessed over the past 50 yr. Steer gains are more influenced by their condition at initial stocking. Those steers that have a substantial amount of fat on them tend not to gain well on grass. If they have a large frame and not too much fat, they tend to gain well on grass (Launchbaugh 1957).

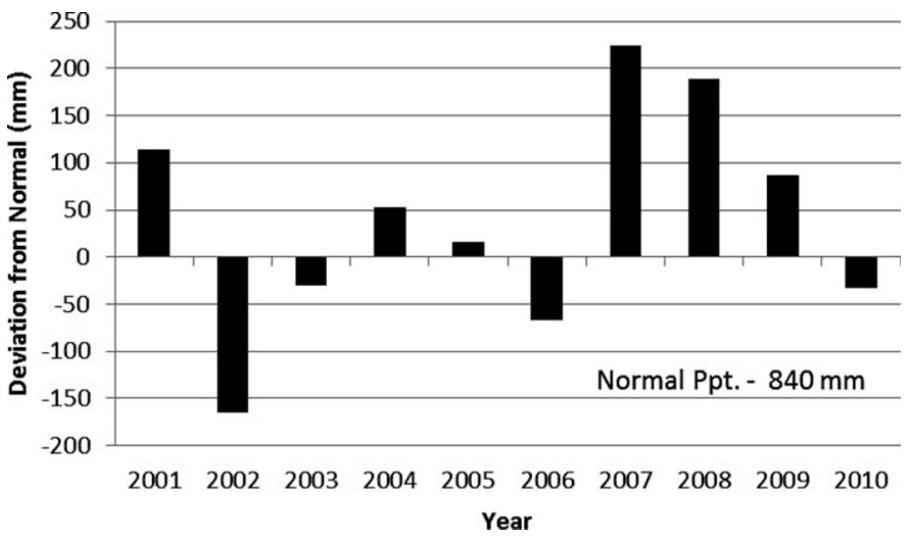

Figure 3. Deviations from normal yearly total precipitation during the study period. 


\section{MANAGEMENT IMPLICATIONS}

Using IES + LSG to precondition forage by grazing heavily early and reducing stocking rate in the latter half of the grazing season increases net returns and appears to be sustained over a substantial time period. Landowners with a fixed land resource can increase net returns without increased fixed costs. Rotating the IES+LSG pasture with SLS across years appears to be a practice that can be utilized in the Kansas Flint Hills. Although we did not sort by weight and retain the lighter steers, the producer could retain the lighter steers on the IES + LSG pasture during the latter half of the growing season so that they could reach a desired weight for entering the feedlot. An additional benefit of the system proposed here is the lack of necessity for similar-sized pastures. Most grazing systems require relatively uniform size, thereby potentially increasing the capital outlay for additional fencing or water development.

\section{LITERATURE CITED}

Anderson, K. L., E. F. Smith, And C. E. Owensby. 1970. Burning bluestem range. Journal of Range Management 23(2):81-92.

Arsenault, R., and N. OWEn-Smith. 2002. Facilitation versus competition in grazing assemblages. Oikos 97:313-318.

Briske, D. D., J. D. Derner, J. R. Brown, S. D. Fuhlendorf, W. R. Teague, K. M. Havstad, R. L. GILLEN, A. J. Ash, AND W. D. WiLms. 2008. Rotational grazing on rangelands: reconciliation of perception and experimental evidence. Rangeland Ecology \& Management 61(1):3-17.

BrISKE, D. D., AND J. W. StuTH. 1982. Defoliation in a moderate and heavy grazing regime. Journal of Range Management 39(4):511-514.

Brock, B. L. 1997. GIS-based analysis and modeling of grazing patterns of domestic cattle (Bos taurus) under two grazing systems in a tallgrass prairie [thesis]. Manhattan, KS, USA: Kansas State University. 107 p.

Chapin, F. S., III, AND S. J. McNaughton. 1989. Lack of compensatory growth under phosphorus stress in grazing-adapted grasses from the Serengeti Plains. Oecologia 79:551-557.

Clark, P. E., W. C. Krueger, L. D. Bryant, and D. R. Thomas. 1998. Spring defoliation effects on bluebunch wheatgrass: I. winter forage quality. Journal of Range Management 51(5):519-525.

Coughenour, M. B. 1991. Spatial components of plant-herbivore interactions in pastoral, ranching and native ungulate ecosystems. Journal of Range Management 44(6):530-542.

Dhurvetter, K. C. 2012. Summer grazing of steers in eastern Kansas. Available at: http://www.agmanager.info/livestock/budgets/projected/default.asp. Accessed 6 June 2012.
Harmoney, K. R., and J. R. Jaeger. 2011. Animal and vegetation response to modified intensive-early stocking on shortgrass rangeland. Rangeland Ecology \& Management 64(6):619-624.

HoBBS, N. T., AND D. M. SwIFT. 1988. Grazing in herds: when are nutritional benefits realized?. The American Naturalist 131(5):760-764.

Holechek, J. L., H. Gomez, F. Molinar, and D. Galt. 1999. Grazing studies: what we've learned. Rangelands 21(2):12-16.

Kansas Farm Management Association. 2012. Monthly feeder cattle and western Kansas slaughter cattle prices-includes value of gain and seasonal price indices. Available at: http://www.agmanager.info/livestock/marketing/database/default. asp. Accessed 6 June 2012.

Lamb, J. B., D. C. Adams, T. J. Kloffenstein, W. W. Stroup, and G. P. Lardy. 1997. Range or meadow regrowth and weaning effects on 2-year-old cows. Journal of Range Management 50(1):16-19.

Launchbaugh, J. L. 1957. The effect of stocking rate on cattle gains and on native shortgrasses vegetation in west-central Kansas. Fort Hays, KS, USA: Fort Hays Branch, Kansas Agricultural Experiment Station. Bulletin 394. 29 p.

Launchbaugh, J. L., AND C. E. OwensBy. 1978. Kansas rangelands: their management based on a half century of research. Manhattan, KS, USA: Kansas Agricultural Experiment Station. Bulletin 622. $56 \mathrm{p}$.

McNaughton, S. J. 1986. Grazing lawns: animals in herds, plant form, and coevolution. The American Naturalist 124:863-886.

Milchunas, D. G., A. R. Mosier, J. A. Morgan, D. R. Lecain, J. Y. King, and J. A. Nelson. 2005. Elevated $\mathrm{CO}_{2}$ and defoliation effects on a shortgrass steppe: forage quality versus quantity for ruminants. Agriculture, Ecosystems, and Environment 111:166-184.

Owensby, C. E., L. M. Auen, H. F. Berns, and K. C. Dhurvetter. 2008. Grazing systems for yearling cattle on tallgrass prairie. Rangeland Ecology \& Management 61:204-210.

Owensby, C. E., E. F. Smith, And J. R. Rains. 1977. Carbohydrate and nitrogen reserve cycles for continuous, season-long, and intensive early-stocked Flint Hills bluestem range. Journal of Range Management 30(4):258-260.

PiesCHEL H. A. 1980. Factors affecting milk and grass consumption of calves grazing native range [thesis]. Manhattan, KS, USA: Department of Agronomy, Kansas State University. $81 \mathrm{p}$.

PITT, M. D. 1986. Assessment of spring defoliation to improve fall forage quality of bluebunch wheatgrass (Agropyron spicatum). Journal of Range Management 39(2):175-181.

Ring, C. B., R. A. Nicholson, and J. L. Launchbaugh. 1985. Vegetational traits of patchgrazed rangeland in west-central Kansas. Journal of Range Management 38(1):51-55.

Smith, E. F., AND C. E. OwENSBy. 1978. Intensive early-stocking and season-long stocking of Flint Hills bluestem range. Journal of Range Management 31(1):14-18.

Streeter, C. L., C. B. Rumburg, T. H. Hall, and E. G. Siemer. 1974. Meadow forage quality, intake, and milk production of cows. Journal of Range Management 27(2):133-135.

Verweis, R. J. T., J. Verrelst, P. E. Loth, I. M. A. Heitkonig, and A. M. H. Brunsting. 2006. Grazing lawns contribute to the subsistence of mesoherbivores on dystrophic savannas. Oikos 114:108-116. 